\title{
ASPEK SOSIAL EKONOMI DAN KELEMBAGAAN SISTEM USAHA PERIKANAN (SUP) BUDIDAYA IKAN PATIN DI PROPINSI JAWA BARAT
}

\author{
Yayan Hikmayani'), Sonny Koeshendrajana"), Abdul Wahid") dan Zahri Nasution")
}

\begin{abstract}
ABSTRAK
Riset yang bertujuan mengetahui aspek sosial ekonomi dan kelembagaan sistem usaha perikanan (SUP) budidaya ikan patin telah dilakukan di Jawa Barat pada tahun 2002. Riset dilakukan menggunakan metode survai dengan menerapkan teknik wawancara terstruktur yang dipandu daftar pertanyaan. Data yang didapatkan dianalisis secara deskriptif yang diinterpretasikan menggunakan metode logik. Hasil riset menunjukkan bahwa pembenih maupun pendeder mengambil keputusan untuk memilih komoditas ikan patin karena besarnya permintaan. Penentuan lokasi pembenihan dan pendederan terutama didasarkan kepada keberadaan sumber air bersih sedangkan penentuan jumlah induk yang dipelihara lebih didasarkan kepada kemampuan untuk membeli pakan induk. Secara finansial baik usaha pembenihan, pendederan maupun pembesaran ikan patin masih memberikan keuntungan usaha yaitu masing-masing Rp. 14.370.000 per bulan untuk usaha pembenihan, Rp. 990.000.- per bulan untuk usaha pendederan berkisar Rp. 950.000.- hingga Rp. 2.957.500.-, untuk usaha pembesaran ikan patin dalam keramba jaring apung di perairan waduk. Pengorganisasian pembenih dan pendeder diperlukan guna pengaturan keselarasan pola kegiatan usaha pembenihan dan pendederan sehingga kesinambungan produksi benih dapat dilaksanakan sepanjang tahun.
\end{abstract}

ABSTRACT: Sosio economic and institutional aspects of catfish cultured in West Java province. By: Yayan Hikmayani, Sonny Koeshendrajana, Abdul Wahid and Zahri Nasution

A research to evaluate sosio economic and institutional aspects of catfish culture fisheries in West Java was conducted in 2002. Survey method combined with structure interviewed technique was used in this research. Data were analyzed using descriptive method while logical method was used in intepreting the data. Result of the research showed that the breeder and fish seed grower prefered to choose catfish as a commodity to cultured because of high demand. Hatchery locations were choosen based on the availability of clean water. Financial analysis showed that breeding, larva rearing and grow out in fish cage culture profited Rp.14.370.000 per month, Rp.990.000.- per month and between Rp.950.000.- to Rp.2.957.500.-, respectively. The other result of the research showed that organizing larva rearing was necessary in promoting the continuity of production.

KEYWORDS: $\quad$ sosio economic, institutional, catfish culture, West Java

\section{PENDAHULUAN}

Pembangunan perikanan di Jawa Barat diarahkan pada peningkatan produksi ikan, peningkatan devisa non migas, penciptaan lapangan kerja produktif dan peningkatan pendapatan pembudidaya ikan dan nelayan serta peningkatan gizi masyarakat melalui peningkatan konsumsi ikan. Sasaran yang akan dicapai pada tahun 2003 produksi komoditas ekspor hasil perikanan sebesar 72.944 ton yang dihasilkan dari usaha penangkapan ikan sebesar 31.600 ton dan budidaya sebesar 41.344 ton (Dinas Perikanan Jawa Barat, 1999).

Khusus untuk perikanan budidaya, sosok perikanan budidaya yang hendak diwujudkan di
Indonesia adalah sistim usaha perikanan budidaya yang mampu menghasilkan produk yang berdaya saing tinggi, menguntungkan, berkeadilan dan berkelanjutan (Dahuri, 2002). Komoditas perikanan yang dihasilkan oleh usaha perikanan budidaya ini tidak hanya dimaksudkan untuk pasar global guna memperoleh devisa, tetapi juga dalam rangka memenuhi kebutuhan ikan (ketahanan pangan) dalam negeri, sehingga rakyat semakin cerdas dan kuat.

Ikan patin (Pangasius sp) merupakan salah satu komoditas ikan budidaya yang telah cukup lama berkembang di beberapa wilayah di Indonesia seperti Kalimantan Selatan, Sumatera Selatan, Lampung, Jambi dan Jawa Barat. Khususnya di Jawa Barat, budidaya ikan patin telah berkembang sejak tahun

Peneliti pada Pusat Riset Pengolahan Produk dan Sosial Ekonomi Kelautan dan Perikanan

Peneliti pada Balai Riset Perikanan Budidaya Air Tawar, Pusat Riset Perikanan Budidaya 
1990-an hingga saat ini baik berupa kegiatan pembenihan, pendederan maupun pembesaran. Spesies ikan patin yang banyak dibudidayakan adalah Pangasius hypopthalmus atau yang lebih dikenal patin sutchi

Berbagai kegiatan riset yang berhubungan dengan komoditas ikan patin telah banyak dilakukan baik yang dilakukan melalui kerjasama Orstom/IRD, bantuan luar negeri maupun berdasarkan dana pemerintah Indonesia. Kegiatan riset tersebut antara lain berhubungan dengan aspek biologi (Hadie dan Hadie, 2000), nutrisi (Suhenda et al., 2000, dan penyakit (Hambali et al., 1997). Dilain pihak, kegiatan riset yang berkaitan dengan informasi sosial ekonomi pembudidaya ikan ataupun kelembagaan sistem usaha perikanan budidaya ikan patin belum banyak diungkap guna dimanfaatkan bagi pengembangannya lebih lanjut. Oleh karena itu riset yang berhubungan dengan aspek sosial ekonomi dan kelembagaan sistem usaha perikanan (SUP) budidaya ikan patin perlu dilakukan.

Riset ini bertujuan mengetahui beberapa aspek sosial ekonomi dan kelembagaan sistem usaha perikanan (SUP) budidaya ikan patin di Propinsi Jawa Barat. Disamping itu riset ini juga bertujuan untuk mendapatkan data dan informasi mencakup permasalahan dan kendala bagi pengembangannya.

\section{METODE}

Data yang dikumpulkan dalam kegiatan riset ini meliputi data primer dan sekunder. Data primer meliputi data yang berkaitan dengan usaha budidaya ikan patin yaitu yang berhubungan aspek sosial terutama pengambilan keputusan oleh pembudidaya dalam hubungannya dengan pemilihan lokasi usaha dan pemilihan komoditas. Aspek ekonomi terutama data yang berhubungan dengan penerimaan dan biaya pelaksanaan usaha budidaya, sedangkan aspek kelembagaan terutama data yang berhubungan dengan pemasaran ikan hasil produksi pembudidaya. Data sekunder diperoleh dari instansi terkait seperti Dinas Perikanan Propinsi Jawa Barat, terutama yang dalam hubungannya dengan kebijakan pengembangan usaha budidaya ikan patin dan pengorganisasian pembudidaya ikan tersebut di Jawa Barat.

Riset dilaksanakan di setiap tahap usaha budidaya baik pembenihan, pendederan maupun pembesaran di wilayah Propinsi Jawa Barat. Lokasi riset meliputi pusat pembenihan dan pendederan di daerah Bogor, sedangkan untuk pembesaran yaitu di Waduk Cirata Kabupaten Cianjur, Waduk Saguling Kabupaten Bandung dan Waduk Jatiluhur di Kabupaten Purwakarta.

Riset ini dilaksanakan menggunakan metoda survai dengan teknik wawancara langsung terhadap responden atau sumber data (primer dan sekunder) baik yang terstruktur menggunakan panduan daftar pertanyaan (kuesioner) maupun yang tidak terstruktur (Singarimbun dan Effendi, 1989). Pemahaman secara cepat terhadap penyebaran dan sistem usaha perikanan (SUP) budidaya ikan patin dilakukan dengan cara tanya jawab dan diskusi terhadap informan kunci baik di Dinas Perikanan Propinsi Jawa Barat maupun kabupaten terkait di lokasi riset.

Responden dipilih menggunakan cara penarikan contoh sengaja (purposive sampling) untuk sub sistem pembenihan dan pendederan yaitu pusat pembenihan dan pendederan ikan patin di Desa Bojong Jengkol Kecamatan Ciampea, Kabupaten Bogor. Begitu pula untuk sub sistem usaha pembesaran yaitu dipilih pembudidaya ikan yang mengusahakan budidaya ikan patin di masing-masing wilayah yaitu di perairan Waduk Cirata, Saguling dan Jatiluhur.

Analisis data dilakukan secara deskriptif untuk mengungkapkan gambaran keragaan usaha perikanan budidaya ikan patin, baik sub sistem pembenihan, pendederan maupun pembesaran. Pada analisis usaha perikanan, variabel yang akan dianalisis adalah penerimaan, biaya dan pendapatan usaha. Penerimaan budidaya adalah perkalian antara jumlah produk yang dihasilkan dengan harga jual. Biaya usaha budidaya adalah semua pengeluaran yang di pergunakan dalam usaha budidaya yang terdiri dari biaya tetap (fixed cost) dan biaya variabel (variabel cost). Biaya tetap adalah biaya pengeluaran yang tidak tergantung tingkat produksi, sedangkan biaya variabel adalah biaya yang besar kecilnya dipengaruhi oleh produksi yang diperoleh, antara lain untuk pembelian benih, pakan dan tenaga kerja.

Pendapatan usaha adalah selisih antara penerimaan dan biaya. Analisis pendapatan atau keuntungan bertujuan untuk mengetahui komponenkomponen yang terlibat dalam kegiatan usaha dan besar keuntungan yang diperoleh dari usaha yang dilakukannya. Analisis pendapatan usaha pertanian umumnya digunakan untuk mengevaluasi kegiatan usaha pertanian dalam satu tahun dengan tujuan untuk membantu perbaikan pengelolaan usaha (Gittinger, 1986)

Untuk menganalisa pendapatan pembudidaya maka diperlukan nilai beberapa unsur antara lain penyusutan rata-rata inventaris, penerimaan, dan pengeluaran usaha tani. Analisis RC ratio bertujuan untuk melihat seberapa jauh setiap nilai rupiah yang digunakan dalam kegiatan usaha dapat memberikan sejumlah nilai penerimaan sebagai manfaatnya. Kegiatan usaha yang paling menguntungkan mempunyai nilai $\mathrm{RC}$ ratio yang terbesar (Hernanto. 1998). 
Untuk mengetahui pendapatan, penerimaan serta struktur biaya digunakan analisis penerimaan dan biaya. Menurut Soekartawi, 1995, Penerimaan usaha adalah perkalian antara produksi yang diperoleh dengan harga jual dirumuskan dengan:

$$
\begin{aligned}
& T R=Y . \text { Py } \\
& T R=\text { Total penerimaan } \\
& Y=\text { Produksi yang diperoleh dalam usaha } \\
& \text { Py }=\text { Harga produk } Y
\end{aligned}
$$

Sedangkan total biaya merupakan penjumlahan dari biaya tetap dan biaya tidak tetap dirumuskan sebagai berikut:

$$
\begin{aligned}
& T C=F C+V C \\
& T C=\text { Total biaya } \\
& F C=\text { Total biaya tetap } \\
& V C=\text { Total biaya tidak tetap. }
\end{aligned}
$$

Pendapatan usahatani adalah selisih antara penerimaan dan semua biaya dirumuskan sbb:

$$
\begin{aligned}
& \mathrm{KU}=\mathrm{TR}-\mathrm{TC} \\
& \mathrm{KU}=\mathrm{Keuntungan} \text { usaha } \\
& \mathrm{TR}=\text { Total penerimaan } \\
& \mathrm{TC}=\text { Total biaya }
\end{aligned}
$$

Analisis Rasio Penerimaan dan Biaya digunakan untuk mengetahui sejauh mana hasil yang diperoleh dari kegiatan usaha selama satu masa pemeliharaan cukup menguntungkan, dengan menggunakan rumus

$$
\text { RC Ratio }=T R / T C
$$

dimana: TR = penerimaan usaha budidaya patin

$$
\text { TC = biaya usaha budidaya patin }
$$

Kriteria usaha yang digunakan adalah:

RC Ratio> 1, maka usaha untung

$\mathrm{RC}$ Ratio< 1 , maka usaha rugi

RC Ratio= 1, maka usaha impas

Analisis pemasaran dilakukan dengan melihat saluran pemasaran. Pengertian pemasaran adalah segala kegiatan usaha yang diperlukan agar barangbarang hasil produksi mengalir secara lancar ke sektor konsumsi (Kotler dan Amstrong, 1990).

\section{HASIL DAN BAHASAN}

\section{Sub Sistem Usaha Pembenihan}

Metoda pemijahan ikan patin yang dipraktekkan pembudidaya pembenih yang terdapat pada lokasi survai menggunakan metode yang sama yaitu metode pijah rangsang (induced spawning). Menurut metode tersebut, pembenihan dilakukan dengan cara merangsang kematangan gonad induk ikan yang akan dipijahkan agar induk-induk ikan tersebut dapat menghasilkan telur dan sperma yang matang. Telur dan sperma tersebut kemudian dicampurkan dalam suatu wadah tertentu dan diaduk menggunakan bulu ayam sampai rata. Kemudian telur yang telah dicampur sperma tadi ditetaskan dalam suatu hapa penetasan untuk selanjutnya dirawat larvanya Perawatan larva pada lokasi pembenihan dilakukan menggunakan akuarium hingga larva berumur 15 hari. Secara lengkap prosedur pembenihan yang dilakukan pembenih secara garis besar dicantumkan pada Lampiran 1

Pengambilan keputusan tentang penentuan lokasi pelaksanaan pembenihan didasarkan terutama pada ketersediaan sumber air bersih untuk kegiatan pembenihan. Dilain pihak, keputusan tentang tempat pemeliharaan induk ikan yang akan dipijahkan dapat saja dilaksanakan pada kolam di dekat lokasi kegiatan pembenihan atau kolam lain yang berjauhan dengan lokasi pembenihan misalnya di lahan petani.

Keputusan tentang jumlah induk yang dipelihara dilakukan pembenih didasarkan kepada ketersediaan permodalan, ketersediaan kolam induk serta kemampuan untuk membeli pakan induk. Pemeliharaan induk yang dilakukan oleh pembenih telah mengikuti anjuran yang antara lain berasal dari petugas lapangan Balai Benih Ikan dan atau Dinas Perikanan setempat ataupun informasi dari Balai Riset. Anjuran tersebut terutama untuk penggunaan pakan induk yang berprotein tinggi.

Pembenih memilih komoditas patin karena banyaknya permintaan terhadap benih ikan patin ini sehingga usaha ini menjadi sumber utama pendapatan mereka seperti di Bojong Jengkol, Kabupaten Bogor. Kegiatan pembenihan yang dilakukan pembenih ikan dapat dikategorikan dilakukan sepanjang tahun karena mereka tidak dipengaruhi musim pemijahan ikan di alam. Namun tingkat produksi benih yang dicapai pada musim kemarau lebih sedikit dibandingkan dengan musim penghujan. Pada musim penghujan benih yang dihasilkan dapat mencapai 200.000 ekor dari satu pasang induk yang dipijahkan, sedangkan pada musim kemarau hanya mencapai 50.000 ekor.

Secara finansial, usaha pembenihan ikan patin yang dilaksanakan oleh pembenih memberikan keuntungan. Struktur investasi, biaya tetap, biaya operasional, penerimaan usaha, keuntungan usaha pembenihan ikan patin diperlihatkan pada Tabel 1.

Tabel 1 menggambarkan bahwa usaha pembenihan ikan patin secara finansial memberikan keuntungan sebesar Rp.14.370.000 per bulan dengan jumlah investasi sebesar Rp.34.646.000 - meskipun sejauh ini belum disertai rencana pengaturan panen dan 
Tabel 1. Besarnya nilai investasi, biaya tetap, biaya operasional, penerimaan usaha, keuntungan usaha dan RC Ratio usaha pembenihan ikan patin di Desa Bojong Jengkol, Jawa Barat tahun 2002

Table 1. Investment value, fixed cost, variabel cost, revenue, profit and the return cost ratio of catfish breeding in Bojong Jengkol Village, West Java 2002

\begin{tabular}{lc}
\hline \multicolumn{1}{c}{ Uraian/ltem } & $\begin{array}{c}\text { Nilai (Rupiah/bulan)/ } \\
\text { Value (Rupiah/month) }\end{array}$ \\
\hline Investasi/Investment & 34.646 .000 \\
Biaya Tetap/Fixed Cost & 1.491 .550 \\
Biaya Variabel/Variable Cost & 8.130 .000 \\
Total Biaya/Total cost & 9.621 .550 \\
Penerimaan Usaha/Total Revenue & 22.500 .000 \\
Keuntungan Usaha/Total Profit & 14.370 .000 \\
Return Cost Ratio & 2,34 \\
\hline
\end{tabular}

pemasaran. Artinya pemasaran benih hingga saat ini masih mengandalkan hubungan dagang antara pembenih dan beberapa relasinya di daerah konsumen tertentu. Pengorganisasian para pembenih ini pun belum banyak dikelola dan dibina oleh aparat pembina. Tetapi bantuan permodalan untuk para pembenih telah diprogramkan dan dijalankan oleh Dinas Perikanan di Kabupaten Bogor, Jawa Barat.

Hingga saat ini belum ada kelembagaan yang membantu di bidang pemasaran benih ikan patin ini, sehingga terjadi persaingan diantara sesama pembenih, terutama untuk Kabupaten Bogor. Padahal kelembagaan sebagai suatu organisasi merupakan salah satu faktor yang penting sebagai penggerak (prime mover) dalam suatu pembangunan (Pakpahan, 1989). Oleh karena itu, kiranya diperlukan kelembagaan yang memfasilitasi kegiatan pemasaran benih ikan patin ini sehingga sub sistem usaha pembenihan ini dapat berlangsung secara terus menerus sebagai pemacu usaha pembangunan perikanan budidaya ikan patin di Indonesia.

\section{Sub Sistem Pendederan}

Sub sistem pendedéran merupakan kelanjutan dari sub sistem pembenihan yang dilaksanakan dalam kegiatan budidaya. Pendederan benih ikan patin yang terdapat pada lokasi riset dilakukan para pendeder menggunakan kolam tanah. Pakan yang digunakan berupa pakan alami yang berasal dari pemupukan menggunakan pupuk kandang dilakukan oleh petani di desa Bojong Jengkol, Kecamatan Ciampea, Kabupaten Bogor. Pendeder benih ikan patin mengambil keputusan untuk mengusahakan pendederan karena merasa telah mempunyai kemampuan untuk melaksanakannya.

Penentuan lokasi pelaksanaan pendederan antara lain dipertimbangkan berdasarkan sumber air dan ketersediaan tempat/lahan dan wadah yang diperlukan dalam kegiatan pendederan tersebut. Gambaran besarnya investasi, biaya tetap, biaya operasional, penerimaan usaha, keuntungan usaha dan efisiensi usaha pendederan ikan patin dapat dilihat pada Tabel 2.

Usaha pendederan yang dilaksanakan di desa ini tergolong cukup menguntungkan karena nilai perbandingan antara penerimaan dan biayanya lebih besar dari satu. Kegiatan pendederan yang dilakukan pembenih sejauh ini belum disertai rencana pengaturan panen dan pasca panen. Selain itu juga tidak diikuti dengan rencana pemasaran benih yang dihasilkan

Pengorganisasian para pendeder benih inipun belum diatur oleh aparat pembina sehingga mereka tidak memusatkan perhatian pada perencanaan usaha. Akses pasar pendeder benih ikan patin masih sangat terbatas, terutama dalam hal penentuan harga masih dominan ditentukan oleh pembenih dan pembelian ikan hasil pendederan dilakukan kembali oleh pembenih.

Pendeder memilih komoditas patin karena banyaknya permintaan terhadap benih ikan patin ini sehingga usaha mereka dapat menjadi sumber tambahan pendapatan utama mereka. Kegiatan pendederan yang dilakukan pembenih ikan dapat dilakukan sepanjang tahun sesuai dengan 
Tabel 2. Besarnya nilai investasi, biaya tetap, biaya operasional, penerimaan usaha, keuntungan usaha dan efisiensi usaha pendederan ikan patin di Desa Bojong Jengkol, Jawa Barat tahun 2002

Table 2. Investment value, fixed cost, variabel cost, revenue, profit and the return cost ratio of catfish larva rearing in Bojong Jengkol Village, West Java 2002

\begin{tabular}{lc}
\hline \multicolumn{1}{c}{ Uraian/ltem } & $\begin{array}{c}\text { Nilai (Rupiah/bulan)l } \\
\text { Value (Rupiah/month) }\end{array}$ \\
\hline Investasi/Investment & 2.430 .000 \\
Biaya Tetap/Fixed Cost & 238,200 \\
Biaya Variabel/Variable Cost & 1.900 .000 \\
Total Biaya/Total Cost & 2.138 .200 \\
Penerimaan Usaha/Total Revenue & 2.890 .000 \\
Keuntungan Usaha/Total Profit & 990,000 \\
Return Cost ratio & 1,35 \\
\hline
\end{tabular}

ketersediaan benih hasil pemijahan buatan yang dilakukan pembenih.

\section{Sub Sistem Pembesaran}

Pelaksanaan budidaya ikan dalam keramba jaring apung, dilakukan dengan penebaran ikan patin sejumlah 2.000-3000 ekor per petak keramba ukuran $49 \mathrm{~m}^{2}$ dengan ukuran benih 2 inchi. Pemeliharaan dilakukan selama 5 hingga 7 bulan dan pada saat panen dicapai ukuran ikan berkisar 350-700 gram per ekor. Pakan yang digunakan per kolam sebanyak 1,3 ton hingga 2 ton dengan hasil panen berkisar antara $1.100-1.500 \mathrm{~kg}$ per kolam.

Pola pembesaran ikan patin yang dilaksanakan masyarakat adalah sepanjang tahun tanpa perencanaan usaha yang baik. Teknologi produksi yang diterapkan bervariasi mulai dari yang sederhana hingga yang intensif dengan pakan yang dibuat sendiri hingga pakan komersil. Benih yang digunakan hanya satu jenis yaitu ikan patin strain hipopthalmus. Pencegahan dan pengendalian hama penyakit ikan belum dilakukan oleh pembudidaya. Sebagai contoh penggunaan antibiotik untuk pengobatan ikan patin yang terserang penyakit tanpa memperhatikan dosis yang dianjurkan

Berdasarkan fungsinya, Waduk Jatiluhur dapat digolongkan sebagai waduk serbaguna, yang berarti waduk ini dimanfaatkan untuk pemenuhan kepentingan berbagai sektor atau sub sektor seperti pencegahan banjir, pembangkit listrik tenaga air (PLTA), pemasok air untuk keperluan irigasi atau pertanian, industri, permukiman, perikanan dan pariwisata, disamping fungsi sebagai lahan budidaya ikan seperti halnya Waduk Cirata.
Jenis ikan terbanyak yang dibudidayakan pembudidaya ikan di Waduk Jatiluhur adalah ikan mas dan ikan nila. Sebagian pembudidaya lainnya membudidaya ikan bandeng, gurame dan patin. Para pembudidaya ikan dalam pengusahaan jaring apung ada yang menebarkan hanya satu jenis ikan (monokultur) yakni ikan mas dan ada yang menebarkan dua jenis ikan (polikultur) yakni ikan mas dan ikan nila atau ikan patin dan ikan nila.

Pembudidaya ikan lebih banyak yang memilih membudidayakan ikan mas karena relatif mudah dalam mendapatkan benih, lebih tahan terhadap penyakit, pemanenan hasil yang lebih cepat (tiga bulan sudah dapat dipanen) dan penjualan hasil panen dapat dilakukan hampir setiap hari melalui pengumpul. Namun demikian, satu kelemahan ikan mas adalah relatif tidak tahan dan cepat mati saat kandungan oksigen di perairan waduk tersebut menurun sebagai akibat adanya perubahan kualitas air perairan, sedangkan ikan patin relatif tahan terhadap perubahan kondisi air.

Perhitungan secara finansial yang terdiri dari besarnya investasi, biaya tetap, biaya operasional, penerimaan usaha, keuntungan usaha dan efisiensi usaha pembesaran ikan patin dalam keramba jaring apung ganda di Jawa Barat (Waduk Cirata, Jatiluhur dan Saguling) diperlihatkan pada Tabel 3.

Berdasarkan Tabel 3 dapat dilihat bahwa besarnya investasi yang ditanamkan untuk usaha budidaya ikan menggunakan sistem KJA ganda di Waduk Jatiluhur dan Saguling tidak terdapat perbedaan yang besar. Namun demikian, perbedaan yang cukup berarti terlihat pada jumlah biaya operasional yaitu lebih tinggi pada Waduk Saguling. Hal ini sebagai akibat 
perbedaan tingginya padat tebar yang dilaksanakan sehingga intensitas penggunaan pakan yang diterapkan pada Waduk Saguling lebih tinggi, kemudian tergambar pula bahwa efisiensi usaha yang lebih tinggi terdapat pada pembudidaya yang terdapat di Waduk Jatiluhur. Hal ini berhubungan dengan berbagai faktor, antara lain manajemen usaha, termasuk penentuan waktu tebar ikan serta harga jual ikan yang diproduksi lebih tinggi pada Waduk Jatiluhur.

\section{Sub Sistem Pemasaran}

Saluran pemasaran ikan patin di Jawa Barat seperti terlihat pada Gambar 1. Pemasaran meliputi pemasaran benih patin yang melibatkan beberapa antara pembenih dan pedagang atau pendeder biasanya atas dasar saling percaya.

Pemasaran ikan konsumsi melibatkan lembaga pemasaran yaitu pedagang pengumpul yang membeli ikan dari petani jaring apung. Harga ikan konsumsi Rp 4.700,- - Rp.5.600,-/kg untuk ukuran 350-600 gram/ekor. Pembelian ikan patin dalam keadaan hidup mempunyai harga jual yang lebih tinggi yaitu $\mathrm{Rp}$. $6.000,-/ k g$ akan tetapi kapasitas jualnya masih rendah. Ikan konsumsi hidup ini biasanya untuk mensuplai restoran dan hotel. Pembayaran oleh pedagang dilakukan secara tidak tunai dengan jangka waktu 2 minggu sampai satu bulan. Masalah yang sering dihadapi dalam pemasaran ikan konsumsi,

Tabel 3. Nilai investasi, biaya tetap, biaya operasional, penerimaan usaha, keuntungan usaha dan RC Ratio pembesaran ikan patin di perairan waduk dalam Propinsi Jawa Barat Tahun 2002

Table 3. Investment value, fixed cost, variabel cost, revenue, profit and return of cost ratio of catfish grow out in cage culture in West Java Reservoar, 2002

\begin{tabular}{|c|c|c|c|}
\hline Uraian/ltem & $\begin{array}{c}\text { Waduk } \\
\text { Jatiluhur,Kab. } \\
\text { Purwakarta } \\
\text { (Jatiluhur } \\
\text { reservoar in } \\
\text { Purwakarta) } \\
\text { (Rupiah/7 } \\
\text { month) }\end{array}$ & $\begin{array}{l}\text { Waduk } \\
\text { Cirata, Kab. } \\
\text { Cianjur } \\
\text { (Cirata } \\
\text { reservoar in } \\
\text { Cianjur) } \\
\text { (Rupiah/7 } \\
\text { month) }\end{array}$ & $\begin{array}{c}\text { Waduk } \\
\text { Saguling, Kab. } \\
\text { Bandung } \\
\text { (Saguling } \\
\text { reservoar in } \\
\text { Bandung) } \\
\text { (Rupiah/7 } \\
\text { month) }\end{array}$ \\
\hline Investasi/Investment & 4.050 .000 & 3.030 .000 & 3.025 .000 \\
\hline Biaya Tetap/Fixed Cost & 425,000 & 315,000 & 625,000 \\
\hline Biaya Variabel/Variable Cost & 6.460 .000 & 7.442 .500 & 12.770 .000 \\
\hline Total Biaya/Total Cost & 6.885 .000 & 7.757 .500 & 13.395 .000 \\
\hline Penerimaan Usaha Total/Total Revenue & 9.840 .000 & 10.662 .500 & 14.686 .000 \\
\hline Penerimaan Usaha Patin/Revenue for Catfish & 7.840 .000 & 10.400 .000 & 13.720 .000 \\
\hline Keuntungan Usaha Total/Total Profit & 3.380 .000 & 3.220 .000 & 1.916 .000 \\
\hline Keuntungan Usaha Patin/Profit for Catfish & 1.380 .000 & 2.957 .500 & 950,000 \\
\hline RC Ratio total/RC Ratio for Total & 1,43 & 1,37 & 1,10 \\
\hline RC Ratio usaha patin/RC Ratio for Catfish & 1,14 & 1,34 & 1,02 \\
\hline
\end{tabular}

lembaga pemasaran yaitu pedagang benih yang melakukan pendederan selama 15-30 hari kemudian menjualnya ke petani pembesar baik yang berada di Jawa Barat bahkan sampai ke Jambi dan Sumatera Selatan. Selain itu ada juga petani pendeder khusus yang memelihara sampai ukuran mencapai 2-2,5 inch dan siap dijual ke petani pembesar melalui pedagang. Harga benih patin Rp 60,- - Rp 75,-lekor, bahkan karena keterbatasan sarana akuarium banyak pembenih yang melakukan penjualan telur ikan dengan harga Rp 600.000,- untuk 100.000 butir. Pembayaran biasanya dilakukan secara kontan dan hubungan biasanya waktu panen tidak dapat ditentukan karena harus mencari pembeli dulu dikarenakan pedagang yang membeli ikan patin sangat terbatas jumlahnya.

Potensi pasar ikan patin konsumsi hasil budidaya di Waduk Cirata, Jatiluhur dan Saguling masih terbatas untuk wilayah Jawa Barat, dan DKI Jakarta. Ukuran ikan patin yang diminati di atas 500 gram/ekor. Fluktuasi harga ikan patin dipengaruhi oleh musim ikan laut. Saat musim ikan laut maka permintaan ikan patin berkurang. Konsumen lebih memilih ikan jambal laut daripada ikan patin karena harganya yang lebih murah. 


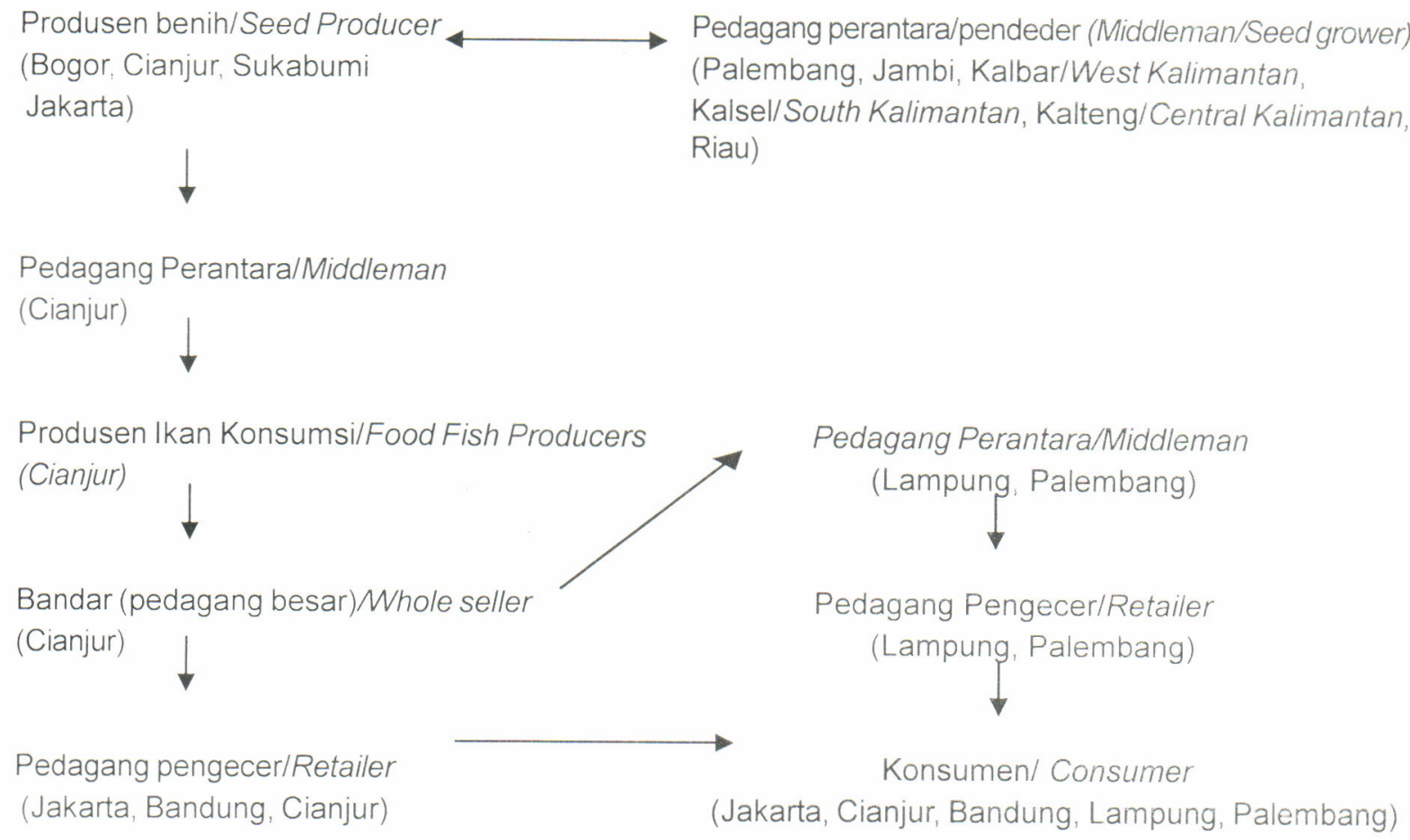

Gambar 1. Saluran pemasaran ikan patin hasil budidaya di Jawa Barat, Tahun 2002 Figure 1. Marketing channel for catfish cultured in West Java, 2002

\section{Kebijakan dan Permasalahan Perikanan Budidaya Ikan Patin}

Kebijakan perikanan budidaya ikan patin yang dimaksudkan dalam hal ini adalah bagaimana keadaan kebijakan di bidang usaha perikanan tersebut pada wilayah setempat. Artinya, usaha perikanan ikan patin saat ini apakah telah berkembang sesuai dengan kebijakan yang ada terutama kebijakan pemerintah setempat (dalam hal ini dapat saja Dinas Perikanan Propinsi ataupun Kabupaten dan atau Pengelola Perikanan lainnya yang terkait dengan pengambilan kebijakan perikanan ikan patin tersebut).

Disamping itu, hasil akhir yang didapatkan pembudidaya berhubungan erat dengan semangat kewirausahaan (entepreneurship) pembudidaya tersebut. Semangat kewirausahaan ini pada akhirnya akan berpengaruh kepada sejauh mana pembenih tersebut akan bekerja dengan sungguh-sungguh dan mengelola (management) usahanya sebagai suatu usaha yang bersifat komersil. Pengelolaan suatu usaha yang bersifat komersil akan memperhitungkan segala masukan sebagai korbanan untuk mendapatkan hasil (output) (Gittinger, 1986).

Hasil akhir tersebut juga berhubungan erat dengan kurangnya dukungan kebijakan pemerintah setempat terhadap sistem usaha perikanan budidaya ikan patin.
Hal ini terlihat bahwa untuk semua wilayah riset komoditas ikan patin tidak menjadi prioritas untuk dikembangkan baik untuk pemenuhan kebutuhan dalam negeri ataupun untuk ekspor. Pembudidaya ikan patin terutama dalam kegiatan pembesarannya belum ada pengaturan waktu tanam antar wilayah yang melakukan usaha tersebut sehingga sering terjadi penurunan harga pada saat panen dilakukan sebagai akibat kompetisi ikan patin hasil budidaya terhadap ikan hasil tangkapan di perairan umum dan kompetisi terhadap ikan patin hasil budidaya di wilayah lainnya yang masih dalam satu wilayah kabupaten/kota atau propinsi.

Permasalahan utama yang yang dihadapi pembudidaya antara lain adalah kurang atau terbatasnya permodalan untuk berusaha karena usaha pembudidayaan ikan patin, baik pembenihan, pendederan maupun pembesarannya membutuhkan modal yang cukup besar. Permodalan tersebut lebih terasa pada usaha pembesaran ikan disebabkan waktu pemeliharaan yang cukup lama sehingga kebutuhan untuk pembelian pakan lebih besar dibandingkan dengan pemeliharaan ikan mas, selain itu perputaran uang menjadi lebih lama. Selain modal, masalah lain adalah mutu benih ikan patin yang masih rendah sehingga mengakibatkan kerugian akibat kematian saat pemeliharaan dan mudah 
terserang penyakit. Khusus untuk lokasi Waduk Saguling menurunnya daya dukung perairan serta adanya serangan penyakit dan limbah perairan mengakibatkan kematian total terjadi pada ikan budidaya sehingga petani sangat dirugikan.

Kendala utama yang dihadapi pembenih antara lain menurunnya mutu induk sehingga gonad yang didapatkan tidak banyak menghasilkan larva yang siap tebar atau siap didederkan dan atau dibesarkan dalam kolam dan atau karamba jaring apung. Kendala lainnya yang dihadapi pembudidaya dalam kegiatan pembesaran ikan patin adalah masaiah pengadaan benih yang tidak tersedia secara cukup di tingkat pembudidaya sehingga harga benih menjadi lebih mahal. Disamping itu, kendala harga pakan dan ketiadaan pakan alternatif yang berharga murah sehingga komponen biaya terbesar terdapat pada pakan.

Ketiadaan pengorganisasian pembudidaya terutama dalam hal pemasaran hasil mengakibatkan pembudidaya terutama dalam kegiatan pembesaran ikan patin tidak mempunyai posisi adu tawar dalam penentuan harga hasil produksinya. Artinya mereka menerima harga yang ditentukan oleh pedagang yang membeli saja tanpa ada sesuatu kekuatan yang dapat meningkatkan harga tersebut. Pengorganisasian ini terkait pula dengan pembinaan budidaya ikan terutama dalam hubungannya dengan pengaturan waktu tanam dan pengendalian dan pencegahan penyakit serta keamanan ikan budidaya.

\section{KESIMPULAN DAN SARAN}

Pembudidaya ikan baik pembenih maupun pendeder mengambil keputusan untuk memilih komoditas ikan patin karena besarnya permintaan terhadap benih ikan tersebut. Di lain pihak penentuan lokasi pembenihan dan pendederan terutama didasarkan kepada keberadaan sumber air bersih dan penentuan jumlah induk yang dipelihara lebih didasarkan kepada kemampuan untuk membeli pakan induk. Pemilihan usaha pembesaran ikan patin lebih didasarkan kepada ketahanan ikan tersebut terhadap keadaan kualitas air waduk yang kadang-kadang menurun

Secara finansial baik usaha pembenihan, pendederan maupun pembesaran ikan patin masih memberikan keuntungan usaha yaitu masing-masing Rp.14.370.000,- per bulan untuk usaha pembenihan, Rp.990.000.- per bulan untuk usaha pendederan dan berkisar Rp.950.000 - - Rp.2.957.500 - untuk usaha pembesaran ikan patin dalam keramba jaring apung di perairan waduk. Gambaran kelayakan usaha tersebut ditunjukkan pula oleh nilai perbandingan antara total penerimaan dan total biaya (return cost ratio) yaitu 2,34 untuk usaha pembenihan, 1,35 untuk usaha pendederan dan berkisar antara 1,02 hingga 1,34 untuk usaha pembesaran.

Pengorganisasian pembenih dan pendeder diperlukan guna pengaturan pola kegiatan usaha pembenihan dan pendederan sehingga kesinambungan produksi benih dapat dilaksanakan sepanjang tahun. Pada usaha pembesaran, meskipun sudah ada kelompok pembudidaya ikan dan pembinaan dari pengelola waduk, tetapi pengaturan pola tanam yang dikaitkan dengan pengaturan panen dan peningkatan harga belum tampak diutamakan sehingga usaha pembesaran ikan patin tersebut belum memberikan kontribusi yang menonjol pada kegiatan usaha budidaya ikan sistem keramba jaring apung di perairan waduk.

Beberapa saran yang diajukan berdasarkan hasil riset ini antara lain diperlukan adanya bantuan modal bagi pembudidaya khususnya kepada pembenih dan pendederan sesuai dengan keperluannya, pembudidaya ikan di perairan waduk perlu dukungan kelembagaan pemasaran yang dapat memfasilitasi usahanya. Sosialisasi dan pengadaan induk ikan patin unggul seperti Pangasius djambal pada Balai Benih Ikan di wilayah tersebut diperlukan untuk membantu agar dihasilkannya benih ikan patin yang lebih unggul dibandingkan benih yang dihasilkan saat ini.

Penyediaan pakan buatan yang berharga murah dapat pula menjadi alternatif meningkatkan keuntungan usaha pembudidaya ikan yang mengusahakan budidaya ikan patin sistem keramba jaring apung di perairan waduk. Akhirnya pengorganisasian pembudidaya terutama dalam hal pemasaran hasil terutama dalam hubungannya dengan pengaturan waktu tanam dan pengendalian dan pencegahan penyakit serta keamanan ikan budidaya turut pula menjamin berlangsungnya usaha perikanan budidaya ikan patin tersebut

\section{DAFTAR PUSTAKA}

Dahuri, Rokhmin. 2002. Paradigma Baru Pembangunan Indonesia Berbasis Kelautan. Institut Pertanian Bogor. $233 \mathrm{pp}$

Dinas Perikanan Propinsi Jawa Barat. 1999. Peluang Usaha Perikanan. Dinas Perikanan Propinsi Jawa Barat. $57 \mathrm{pp}$

Gittinger, J.P. 1986. Analisa Ekonomi Proyek-Proyek Pertanian. Universitas Indonesia Press. Jakarta.

Hadie, L.E. dan Hadie, W. 2000, Manajemen keragaman genetik dalam mendukung konservasi ikan secara ex-situ, Seminar Nasional Keanekaragaman Hayati Ikan. Pusat Studi IImu Hayati. LP-IPB dan Puslitbang Biologi LIPI. Bogor. 9 pp.

Hambali, S., Taukhid dan Moekti, G. 1997. Upaya produksi dan karakterisasi hibridoma untuk penanggulangan bakteri penyakit pada ikan: I. Pembentukan hibridoma 
penghasil antibodi monoklonal anti Aeromonas hydrophila. Jurnal Bioteknologi Pertanian Vol. 2, Nomor 1. p. 9-13.

Hernanto, F. 1998. Ilmu Usahatani. Penerbit Penebar Swadaya. Jakarta.

Kotler, P. and Armstrong, G. 1990. Principle of Marketing. Prentice-Hall, Inc. New York.

Singarimbun, M. dan Effendi, S. 1989. Metode Penelitian Survey. LP3ES. Jakarta

Soekartawi. 1995. Analisis Usahatani. Universitas Indonesia Press. $110 \mathrm{pp}$.
Suhenda, N., Tahapari, E., Moreau, Y. and Slembrouck, J. 2000 , Protein deposition and energy utilization in Pangasius djambal, Final Meeting of the "Catfish Asia" Projet, Bogor. Indonesia 15-20 May 2000.

Pakpahan, A. 1989. Kerangka analitik untuk penelitian rekayasa sosial: Persfektif ekonomi institusi. In. Pasandaran, E. dkk: Prosiding Patanas Evolusi Kelembagaan Pedesaan di Tengah Perkembangan Teknologi Pertanian. p.1-18. Pusat Penelitian Agro Ekonomi. Badan Litbang Pertanian. Departemen Pertanian. Jakarta. 


\section{Lampiran 1. Bahan dan Alat serta Teknologi Pembenihan Ikan Patin}

\section{A. Bahan-bahan}

- $\quad$ Induk ikan patin betina matang gonad (siap pijah)

- Induk ikan patin jantan matang gonad

- Hormon perangsang ovulasi telur (Ovaprim, HCG, ekstrak hypofisa)

- Sodium chlorida $(0,9 \%)$

- Larutan penjernih telur/ larutan sera (alkohol: asam asetat: formalin = 3:1:6)

- Garam

- Pakan buatan dengan kandungan protein 28\% dan 35\%

- Fakan untuk hrva dan ben in (Artemia, Tubifex hidup dan Moina sp)

- Bahan-bahan untuk persiapan kolam seperti pupuk kandang, kapur ( $\mathrm{CaO})$

\section{B. Alat-alat dan sarana}

- Kolam pemeliharan induk ukuran $(30 \times 20 \times 1,5) \mathrm{m}^{3}$

- Hapa untuk inkubasi induk ukuran $(2 \times 1 \times 1,2) \mathrm{m}^{3}$

- Hapa untuk penampungan benih ukuran $(3 \times 2 \times 1,2) \mathrm{m}^{3}$

- Aquarium untuk penetasan telur / pemeliharaan larva $(60 \times 50 \times 40) \mathrm{cm}^{3}$, fiber glass volume 500 1000 liter.

- Corong penetasan telur.

- Kolam tanah atau bak beton untuk pendederan benih $500 \mathrm{~m}^{2}$,

- Alat-alat perikanan di lapangan : gayung, ember, waskom, saringan, selang, serok, jaring, dan waring.

- $\quad$ Alat suntik (spuit dan gelas atau plastik volume 2 cc dan $10 \mathrm{cc}$ )

- Blower dan instalasinya

- Alat ukur kualitas air: Termometer, pH meter, dan DO meter.

\section{Teknologi Pembenihan}

\section{C.1. Pemeliharaan Induk}

- Induk dipilih dari ikan patin yang sehat dan tidak cacat, umur lebih dari 2,5 tahun untuk induk betina sedangkan untuk induk jantan umur 2 tahun dengan bobot $2,0 \mathrm{~kg}$

- Sebelum, dipijahkan induk jantan dan betina dipelihara dalam kolam berukuran $(30 \times 20 \times 1,5) \mathrm{m}^{3}$ dengan kepadatan $0,5-1,0 \mathrm{Kg} / \mathrm{m}^{3}$.

- Untuk mempercepat kematangan gonad, induk diberi pakan pellet dengan kadar protein minimal 35 $\%$ sebanyak 1,5 - $2 \%$ /berat biomassa/hari.

- Frekuensi pemberian pakan dilakukan 2 kali per hari pada pagi dan sore hari

\section{C.2. Seleksi Induk Matang Gonad}

- Pengecekan tingkat kematangan gonad induk dilakukan 1 minggu sekali.

- Penangkapan induk dilakukan dengan menggunakan jaring yang dilengkapi dengan pelampung dan pemberat

- Induk yang tertangkap dibedakan jenis kelamin dan tingkat kematangan gonadnya. 
Tanda induk matang gonad adalah sebagai berikut:

- Induk betina : bagian perutnya terlihat membuncit, lubang genital menonjol dan berwarna kemerahmerahan.

- Contoh telur diambil dengan menggunakan kateter, kemudian diamati tingkat kematangannya secara visual.

Induk yang siap untuk dipijahkan ditandai dengan ukuran telurnya seragam dengan diameter 1,0 - 1,2 $\mathrm{mm}$ dan jika direndam dalam larutan sera terlihat jelas inti telurnya, mudah dipisahkan dan tidak ada lendir

- Induk jantan : bagian perut terlihat biasa, bentuk alat kelamin menonjol. Bila dipijit bagian perut ke arah lubang genital akan mengeluarkan cairan sperma berwama putih susu.

\section{C.3. Pemijahan Buatan}

- Pemijahan dilakukan secara buatan yaitu dengan penyuntikan hormon. Jenis hormon yang digunakan adalah ovaprim dengan dosis $0,6-0,9 \mathrm{cc} / \mathrm{kg}$ induk untuk induk betina, dan 0,3 cc untuk induk jantan.

- Sebelum induk disuntik, terlebih dahulu ditimbang beratnya untuk menentukan hormon yang akan digunakan.

- Penyuntikan dilakukan dua kali dengan interval waktu penyuntikan 8 jam, untuk penyuntikan I digunakan $1 / 3$ dari dosis dan 2/3 sisanya -untuk- penyuntikan ke dua.

- Penyuntikan dilaksanakan secara intra muscular dibagian kiri/kanan belakang sirip punggung.

- Posisi jarum suntik terhadap tubuh induk membentuk sudut $30-40^{\circ} \mathrm{C}$ sejajar dengan panjang tubuh.

- Waktu ovulasi terjadi berkisar antara 5 - 6 jam setelah penyuntikan ke 2 (kisaran suhu $29-30^{\prime} \mathrm{C}$ ) ditandai dengan keluarnya telur bila dilakukan pengurutan pada bagian perut.

- Telur dan sperma dikeluarkan dengan cara pengurutan perut kemudian ditampung di dalam mangkuk.

- Pembuahan buatan dilakukan dengan cara mencampurkan telur dengan sperma yang telah diencerkan dengan larutan sodium chlorida $0.9 \%$ kemudian diaduk dengan bulu ayam searah jarum jam selama lebih kurang 2 - 3 menit secara perlahan.

- Selanjutnya telur ditetaskan dalam aquarium pada kisaran suhu $27-29^{\circ} \mathrm{C}$.

\section{C.4. Penetasan Telur}

- Telur yang sudah dibuahi ditetaskan dalam aquarium yang berukuran $(60 \times 50 \times 40) \mathrm{Cm}^{3}$ atau fiber glass bervolume 500 - 1000 liter, atau corong penetasan.

- Sebelum wadah digunakan, dilakukan. pencucian sampai bersih kemudian dikeringkan, selanjutnya diisi air setinggi $25-30 \mathrm{~cm}$.

- Sebelum. penebaran telur, dilakukan pengukuran suhu pada media penetasan. Bila suhu air terlalu rendah, maka perlu dipasang permanas air (Water-heatertermostat).

- Padat penebaran telur dalam aquarium sebanyak 25 cc/akuarium, atau setiap $1 \mathrm{cc}$ telur ( 800 butir) ditebar pada luasan aquarium $120 \mathrm{~cm}^{2}$ atau $200 \mathrm{~g} /$ corong.

- Penetasan telur berlangsung selama $24-26$ jam pada kisaran suhu $27-29^{\circ} \mathrm{C}$.

\section{C.5. Penghitungan dan Pengepakan Larva}

Penghitungan larva dilakukan secara sampling acak dengan volume tertentu, sebelum dilakukan pengambilan dilakukan pengadukan secara perlahan sehingga larva akan tersebar secara merata, kemudian hasil penghitungan dikalikan dengan total volume wadah.

- Untuk pengepakan larva disesuaikan lama/jarak pengangkutan. 
Setelah dilakukan penghitungan, larva dimasukkan ke dalam plastik dengan volume 10 liter, dimana jumlah air $1 / 3$ volume, 2/3 oksigen.

- Untuk lama pengangkutan lebih kurang 4 jam kepadatan larva 20.000/ kantong

- Pengangkutan dilakukan dalam kondisi suhu sejuk.

\section{C.6. Pemeliharaan Larva}

- Setelah telur menetas seluruhnya, larva dipindahkan ke aquarium/fiberglass lain yang telah dipersiapkan.

- Pemindahan larva dilakukan pada pagi atau sore hari, yaitu ketika larva sudah berumur 6 - 8 jam setelah menetas, dengan cara diserok dengan serok halus atau plankton net, kemudian ditebar dalam akuarium/fiber glass dengan kepadatan 40 ekor/liter.

- Selama pemeliliaraan larva, pakan yang diberikan adalah nauplii artemia sp dan cacing rambut (Tubifek) yang hidup.

- Nauplii Artemia sp. diberikan pada larva umur 2 - 8 hari, sedangkan cacing rambut diberikan setelah larva berumur 7 hari.

Frekuensi pemberian pakan dilakukan 5 kali per hari yaitu pada pukul 07.00, 11.00, 15.00, 19.00, dan 23.00 WIB secara ad libitum.

\section{Pengelolaan Kualitas Air}

Agar kualitas air tetap baik dilakukan penyifonan kotoran yang mengendap di dasar akuarium dan penggantian air sebanyak 30-50\% / 2 hari.

- Penyifonan dilakukan 1 kali per hari pada pagi hari sebelum pemberian pakan. Pemeliharaan larva dalam akuarium dilakukan selama 12 - 15 hari.

\section{E. Panen Benih}

\section{Pemanenan dilakukan setelah larva berumur 12 - 15 hari.}

- Pemanenan dilakukan dengan cara penurunan volume air dengan menggunakan slang yang dilengkapi dengan saringan, kemudian larva yang tertinggal dengan sedikit air dituangkan kedalam waskom

- Benih yang tertampung di dalam waskom siap untuk dihitung.

- Penghitungan benih dilakukan dengan hati-hati dan selama penghitungan waskom selalu dilengkapi dengan aerasi 